\title{
A Cytogenetic Study of Familial Deafness
}

\author{
H. DAR and S. T. WINTER \\ From the Department of Paediatrics and Sol Gold Laboratory, Rothschild Hospital, Haifa, Israel
}

Grimaud, Gilgenkrantz, and Bemol (1967) reported identical chromosomal abnormalities in two children with isolated deafness, and discussed the possible relation between the observed anomalies and particular types of hearing defect.

Hearing impairment is sometimes present in syndromes associated with chromosomal abnormalities: about half of a group of patients with ovarian dysgenesis and chromosomal abnormalities were deaf (Engel and Forbes, 1965), and a high percentage of patients with Down's syndrome were also found to have impaired hearing (Francois, MattonVan Leuven, and Kluyskens, 1967).

The heterogeneous group of isolated hereditary deafness includes at least 9 entities (Mengel et al., 1967). If the association of chromosomal abnormalities with some forms of deafness is confirmed, this might be important in diagnostic differentiation, in the study of modes of inheritance, and in genetic counselling, as based on marker chromosomes.

These factors led us to conduct a cytogenetic study of children with familial deafness, who were among a group of children with various forms of deafness attending special hearing clinics in Northern Israel.

\section{Materials and Methods}

Studies were made of 129 children from 63 families, including 3 families with special syndromes (Table I). This number included 87 children from 41 families out of a group of 209 children with congenital familial deafness reported by us (Winter and Dar, 1967). 'Deafness' is defined as a hearing loss of sufficient degree to necessitate the use of special or supplementary methods for the learning of speech. 'Familial deafness' is assumed in a deaf person with a positive family history of deafness in the absence of a known acquired cause. 'Positive family history' refers to the occurrence of deafness in another relative-sib, parent, grandparent, aunt, uncle, or first cousin.

Chromosomes were examined from peripheral blood cultures (Moorhead et al., 1960). Between 25 and 50 cells were studied in 110 cases, and 10 to 15 cells in 19

Received February 4, 1969.
TABLE I

FAMILIAL DEAFNESS IN 129 CHILDREN STUDIED

\begin{tabular}{c|c|c}
\hline & $\begin{array}{c}\text { No. of } \\
\text { Children }\end{array}$ & $\begin{array}{c}\text { No. of } \\
\text { Families }\end{array}$ \\
\hline $\begin{array}{c}\text { Isolated deafness } \\
\text { Syndromes: Waardenburg } \\
\text { Total albinism }\end{array}$ & 124 & 60 \\
Usher & 2 & 1 \\
\hline Total & 2 & 1 \\
\hline & 129 & 63 \\
\hline
\end{tabular}

cases. Three representative karyotypes were made from each preparation, and additional karyotypes were made as necessary.

\section{Results}

Cytogenetic investigation of the 129 children gave the following results. All 129 cases showed a moe dal number of chromosomes- 46 , with a percentage of aneuploidy similar to that reported for the random population sample studied by Court Brown et al. (1966) (Table II). In 111 cases, no abnormalities were observed.

Findings in the other 18 children were as follows (Table III). Four children showed chromatid aberrations in 20 to $30 \%$ of the cells studied, viz. chromatid and isochromatid gaps and breaks, fragments, dicentric chromosomes, and quadriradial configurations (Table IV, Fig. 1 a-d). This percentage of chromatid aberrations is significantly higher than that reported in a random population sample (Court Brown et al., 1966). Of these 4 children, one also showed endoreduplication and

TABLE II

DISTRIBUTION OF CHROMOSOME COUNTS IN 129 DEAF CHILDREN

\begin{tabular}{|c|c|c|c|c|c|c|c|}
\hline $\begin{array}{c}\text { Chromosome } \\
\text { Count }\end{array}$ & $<45$ & 45 & 46 & 47 & $>47$ & Polyploid & Total \\
\hline $\begin{array}{l}\text { No. of cells } \\
\text { Percentage }\end{array}$ & $\begin{array}{l}133 \\
3.91\end{array}$ & $\begin{array}{l}127 \\
3 \cdot 74\end{array}$ & $\begin{array}{l}3057 \\
89 \cdot 86\end{array}$ & $\begin{array}{c}45 \\
1 \cdot 32\end{array}$ & $\begin{array}{c}10 \\
0 \cdot 29\end{array}$ & $\begin{array}{c}30(14)^{\star} \\
0.88(0.41)\end{array}$ & $\begin{array}{c}3402 \\
100 \cdot 00\end{array}$ \\
\hline
\end{tabular}

* Cells showing endoreduplication are indicated by numbers in parentheses. 
TABLE III

CYTOGENETIC RESULTS IN 19 CASES OF FAMILIAL DEAFNESS

\begin{tabular}{|c|c|c|c|c|c|c|}
\hline \multirow[b]{2}{*}{$\begin{array}{l}\text { Case } \\
\text { No. }\end{array}$} & \multirow[b]{2}{*}{$\begin{array}{l}\text { Sex } \\
\text { and } \\
\text { Age } \\
\text { (yr.) }\end{array}$} & \multirow[b]{2}{*}{$\begin{array}{c}\text { Other } \\
\text { Clinical } \\
\text { Abnormalities }\end{array}$} & \multicolumn{4}{|c|}{ Chromosomal Abnormalities } \\
\hline & & & $\begin{array}{l}\text { High \% of } \\
\text { Chromatid } \\
\text { Aberrations }\end{array}$ & $\begin{array}{l}\text { Endo- } \\
\text { reduplication }\end{array}$ & $\begin{array}{c}\begin{array}{c}\text { Elongated } \\
\text { Secondary } \\
\text { Constriction } \\
\text { (Chromosome 9) }\end{array} \\
\end{array}$ & Miscellaneous \\
\hline $\begin{array}{l}159 \\
172 \\
188 \\
207 \\
\end{array}$ & $\begin{array}{l}M 7 \\
F 8 \\
M 7 \\
M 7\end{array}$ & $\begin{array}{l}\text { Total albinism } \\
\text { Severe myopia }\end{array}$ & $\begin{array}{l}+ \\
+ \\
+ \\
+ \\
\end{array}$ & + & & Long chromosome 16 \\
\hline $\begin{array}{l}160 \\
161 \\
162 \\
163 \\
124 \\
125 \\
\end{array}$ & $\begin{array}{ll}M & 10 \\
\mathrm{~F} & 5 \\
\mathrm{M} & 2 \\
\mathrm{~F} & 4 \\
\mathrm{~F} & 9 \\
\mathrm{~F} & 21 \\
\end{array}$ & & & + & $\begin{array}{l}+ \\
+ \\
+ \\
+ \\
+ \\
+\end{array}$ & \\
\hline $\begin{array}{r}74 \\
80 \\
166 \\
176 \\
180 \\
192 \\
200 \\
228\end{array}$ & $\begin{array}{ll}M & 4 \\
M & 14 \\
F & 13 \\
F & 2 \\
M & 5 \\
M & 2 \\
F & 14 \\
F & 1\end{array}$ & & & $\begin{array}{l}+ \\
+ \\
+ \\
+ \\
+ \\
+ \\
+ \\
+\end{array}$ & & \\
\hline 127 & M 9 & & & & & Long chromosome $\mathrm{Y}$ \\
\hline
\end{tabular}

TABLE IV

CHROMATID ABERRATIONS IN 4 CASES

\begin{tabular}{|c|c|c|c|c|c|c|c|}
\hline \multirow{2}{*}{$\begin{array}{l}\text { Case } \\
\text { No. }\end{array}$} & \multirow[b]{2}{*}{ Study } & \multirow{2}{*}{$\begin{array}{c}\text { No. of } \\
\text { Cells } \\
\text { Studied }\end{array}$} & \multicolumn{5}{|c|}{ Chromatid Aberrations } \\
\hline & & & $\begin{array}{c}\text { Gaps } \\
\text { and } \\
\text { Breaks }\end{array}$ & $\begin{array}{c}\text { Acentric } \\
\text { Fragments }\end{array}$ & $\begin{array}{c}\text { Dicentric } \\
\text { Chromosomes }\end{array}$ & $\begin{array}{l}\text { Quadriradial } \\
\text { Configurations }\end{array}$ & $\begin{array}{c}\text { Total No. } \\
\text { of Cells with } \\
\text { Abnormality } \\
(\%)\end{array}$ \\
\hline 159 & $\begin{array}{l}\text { Initial } \\
\text { Repeated }\end{array}$ & $\begin{array}{l}62 \\
64 \\
\end{array}$ & $\begin{array}{r}12 \\
3 \\
\end{array}$ & $\begin{array}{l}8 \\
1 \\
\end{array}$ & 1 & & $\begin{array}{c}21(34 \%) \\
4(6 \%)\end{array}$ \\
\hline 172 & & 48 & 5 & 7 & & 2 & $14(22 \%)$ \\
\hline 188 & $\begin{array}{l}\text { Initial } \\
\text { Repeated }\end{array}$ & $\begin{array}{l}31 \\
91\end{array}$ & $\begin{array}{r}3 \\
12\end{array}$ & $\begin{array}{l}2 \\
1\end{array}$ & & 2 & $\begin{array}{r}7(22 \%) \\
13(14 \%)\end{array}$ \\
\hline 207 & & 58 & 8 & 7 & & 5 & $24(40 \%)$ \\
\hline
\end{tabular}

TABLE V

FAMILY A (PROPOSITUS No. 159)-CHROMOSOMAL RESULTS

\begin{tabular}{|c|c|c|c|c|c|c|}
\hline \multirow[b]{2}{*}{$\begin{array}{l}\text { Case } \\
\text { No. }\end{array}$} & \multirow[b]{2}{*}{$\begin{array}{l}\text { Sex } \\
\text { and } \\
\text { Age } \\
\text { (yr.) }\end{array}$} & \multirow[b]{2}{*}{ Relation } & \multirow[b]{2}{*}{ Hearing } & \multicolumn{3}{|c|}{ Chromosomal Abnormalities } \\
\hline & & & & $\begin{array}{c}\text { Chromosomal } \\
\text { Breakage }\end{array}$ & $\begin{array}{c}\text { Elongated } \\
\text { Secondary } \\
\text { Constriction } \\
(\text { Chromosome 9) }\end{array}$ & $\begin{array}{l}\text { Endo- } \\
\text { reduplication }\end{array}$ \\
\hline $\begin{array}{l}160 \\
161 \\
162 \\
163 \\
164 \\
165\end{array}$ & $\begin{array}{ll}M & 10 \\
F & 5 \\
M & 2 \\
F & 4 \\
F & 27 \\
M & 12\end{array}$ & $\begin{array}{l}\text { Propositus } \\
\text { Sib } \\
\text { Sib } \\
\text { Sib } \\
\text { Sib } \\
\text { Mother } \\
\text { Sib }\end{array}$ & $\begin{array}{l}\text { Deaf } \\
\text { Deaf } \\
\text { Deaf } \\
\text { Deaf } \\
\text { Deaf } \\
\text { Unaffected } \\
\text { Unaffected }\end{array}$ & $\begin{array}{l}\text { Chromatid gaps, } \\
\text { dicentric chromosome, } \\
\text { acentric breakage }\end{array}$ & $\begin{array}{l}+ \\
+ \\
+ \\
+ \\
+\end{array}$ & $\begin{array}{l}+ \\
+\end{array}$ \\
\hline
\end{tabular}




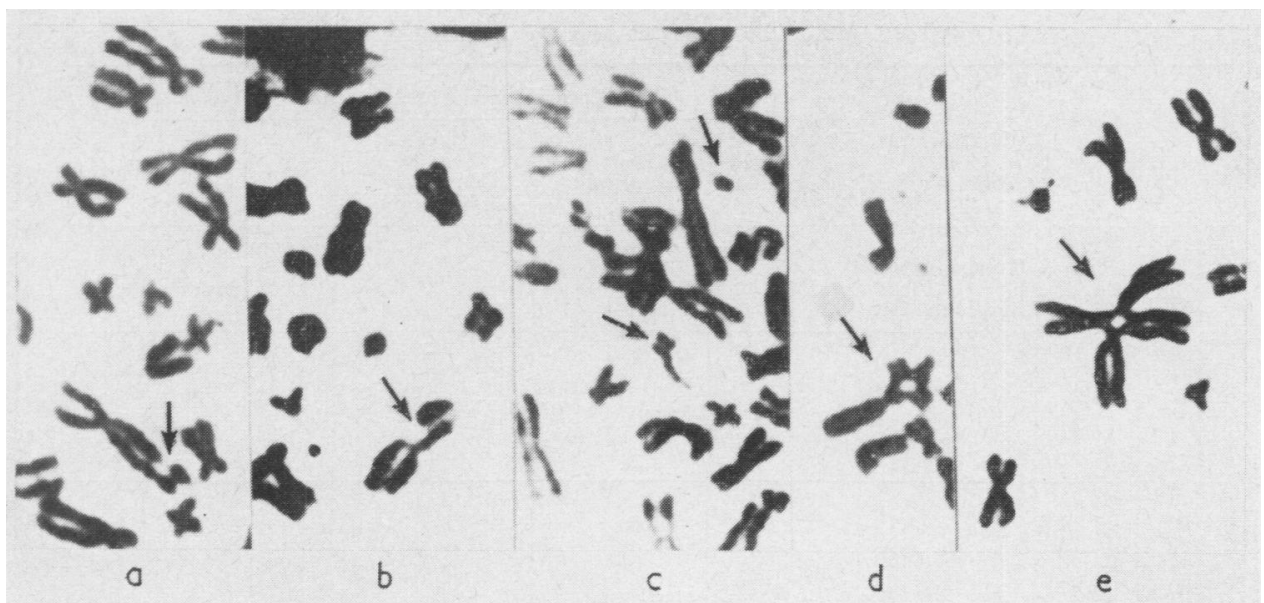

FIG. 1. (a) Chromatid gap; (b) chromatid break; (c) fragment and chromatid deletion; and (d) and (e) quadriradial configurations.

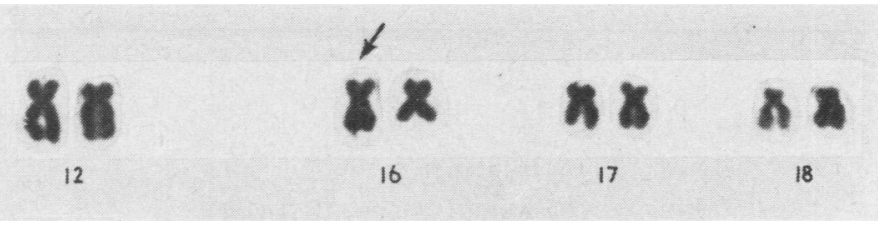

FIG. 2. Heterozygosity of chromosomes 16 .

another showed increased length of one chromosome No. 16 (Fig. 2). Experience in this laboratory over the same period, with 73 patients with normal hearing, showed that in no case did chromatid aberrations exceed $6 \%$. Six children showed conspicuously elongated secondary constriction of chromosome No. 9 (Fig. 3), one also showing endoreduplication; four of these children were from the same family (Family A-Fig. 4). Eight other children, all from different families, showed endoreduplication ( 1 cell in 7 cases, and 3 cells in 1 case) and no other abnormalities.

One child showed an unusually long $\mathrm{Y}$ chromosome, apparently equal in length to chromosome No. 17 (Fig. 5).

There was no history of irradiation, drug therapy, or viral infection in any of these cases.

More detailed studies were made in two families where the propositi showed a high percentage of chromatid aberrations.

Family A. (Propositus-Case 159) (Table V). A Jewish family from Morocco. The parents are first cousins. At the initial examination, the propositus showed various types of chromatid aberrations (chromatid gaps, fragments, and dicentric chromosomes) in $34 \%$ of 62 cells studied (Table IV). All his 4 deaf sibs showed conspicuously elongated secondary constrictions of chromosome No. 9 in $30-50 \%$ of the cells studied: The incidence of chromatid aberrations did not exceed $5 \%$ in any case.

In a further study, 18 months later, the 5 deaf children, their unaffected mother, and the only unaffected sib were examined. The father was not available for the study. The propositus then showed chromatid aberrations in $6 \%$ of 64 cells studied. Quadriradial configuration was noted in one cell of the mother. Several endoreduplications were found in preparations from the mother and in one of the other deaf children (Case 161), with an incidence of 1.6 and $1.2 \%$ in 578 and 550 mitoses scored, respectively. The mother and 4 deaf children showed elongated secondary constriction of chromosome No. 9, similar to that present at the first examination. No abnormalities were observed in the unaffected sib. All family members were otherwise well, and there was no history of irradiation, drug therapy, or viral infection.

Family B. (Propositus-Case 188) (Fig. 6). An Arab family. The parents are not related. Deafness was present among offspring of the sisters of the father and the mother; both were married to their first cousins. The deafness seems to be inherited as a recessive trait. At the initial examination, the propositus showed chromatid aberrations (chromatid gaps, fragments, and quadriradial configurations) in $22 \%$ of 31 cells studied, and increased length of one chromosome No. 16. 


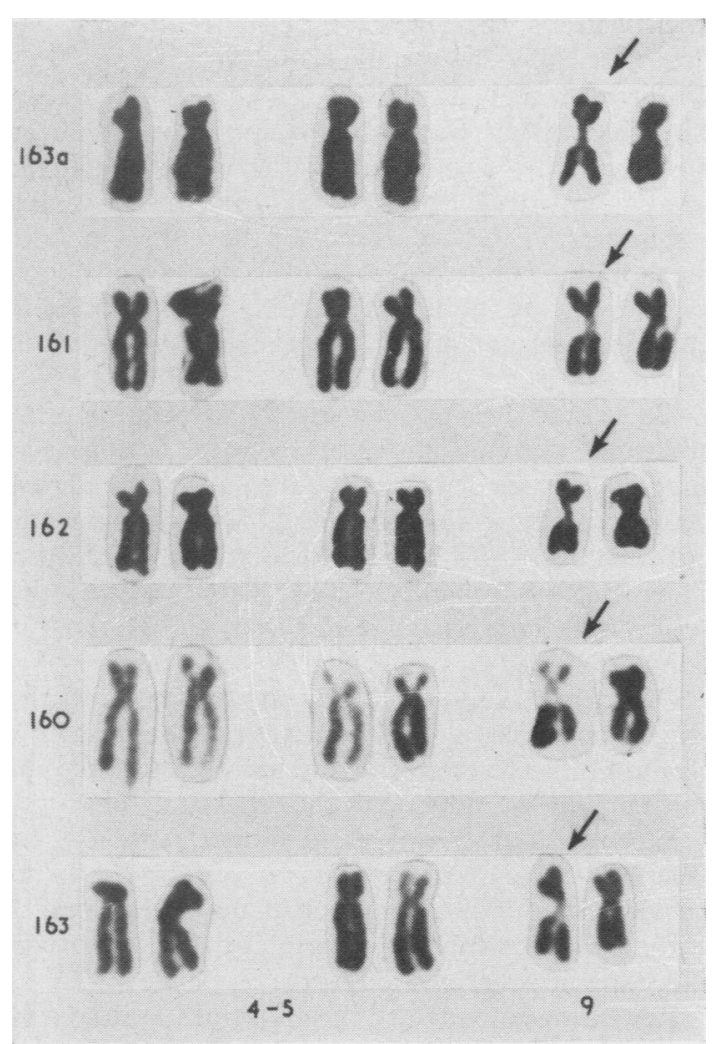

FIG. 3. Elongated secondary constriction in chromosome 9.

Study of one deaf sib (Case 189, Fig. 6) and 3 of his deaf first cousins revealed only endoreduplication in 3 cells in one deaf first cousin (Case 180). Chromosomes No. 16 were normal in each case, and there were no other abnormalities. Other members of the family were not available for the examination.

In a further study, two years later, the propositus showed chromatid aberrations (chromatid gaps and

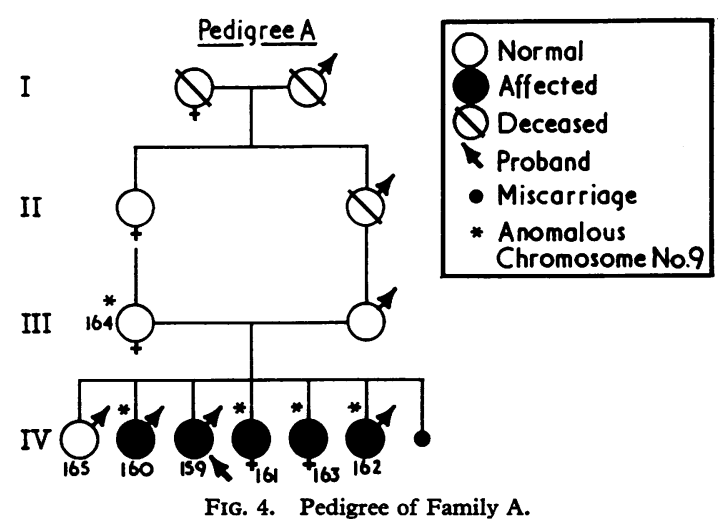

FIG. 4. Pedigree of Family A.

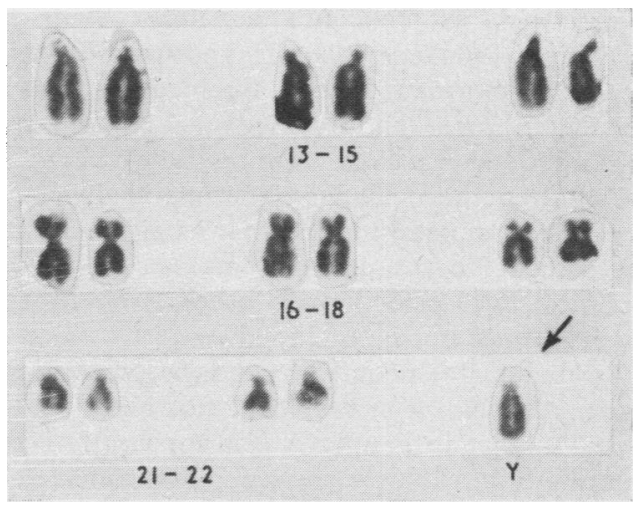

FIG. 5. Long $\mathrm{Y}$ chromosome.

fragments) in $14 \%$ of 91 cells studied. The increased length of one chromosome No. 16 was again noted.

\section{Discussion}

Though unusual findings were noted in the cells of 19 children, it is unlikely that any of them are

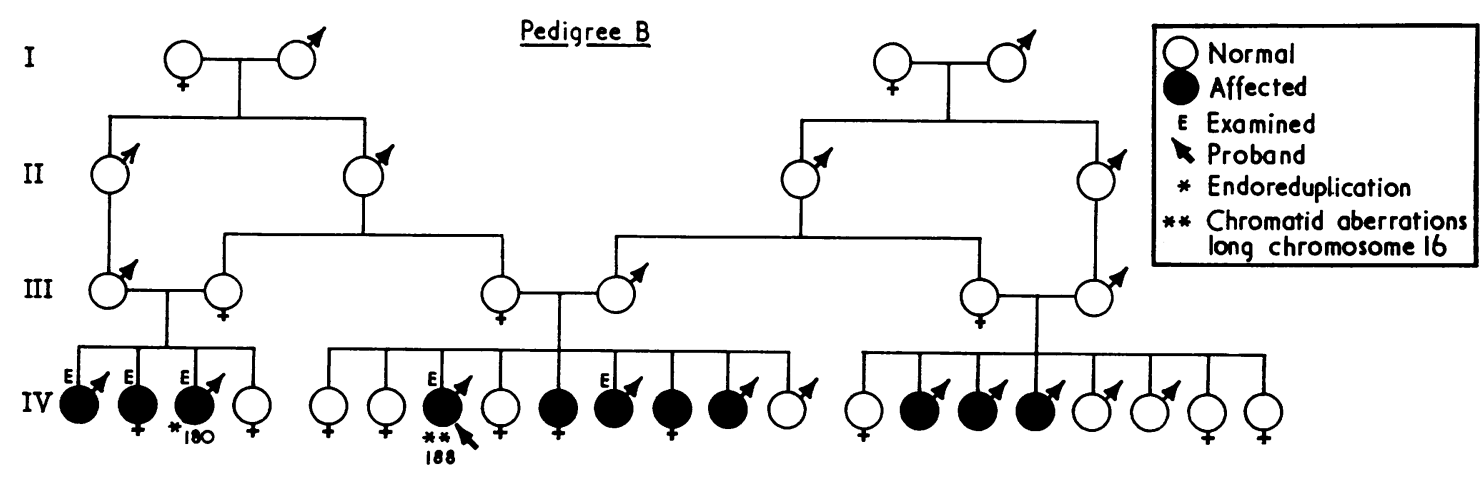

Fig. 6. Pedigree of Family B. 
directly associated with deafness. Each of these abnormalities has been reported in individuals from a random population sample or in patients with normal hearing, who were studied. Chromatid aberrations were recorded in less than $6 \%$ of the cells in a random population sample (Court Brown et al., 1966). Chromatid gaps were the commonest aberration, and chromatid exchange the rarest, being recorded in only about $0.1 \%$ of cells. A high percentage of chromatid aberrations was recorded in patients after irradiation (Court Brown, Buckton, and McLean, 1965), after exposure to drugs (Ryan, Boddington, and Spriggs, 1965; Cohen, Marinello, and Back, 1967), and after viral infections (Nichols, 1966). It also occurs in certain congenital syndromes such as Fanconi's anaemia (Swift and Hirschhorn, 1966) and Bloom's syndrome (Sawitsky, Bloom, and German, 1966). Such causes were not recorded in our 4 children with a high incidence of chromatid aberrations. On repeat studies in 2 of the 4 children, the incidence of chromatid aberrations was reduced, suggesting that there had been transient damage to the chromosomes. A preceding subclinical viral infection or other environmental influence could not be excluded.

Conspicuously elongated secondary constriction of chromosome No. 9 in four deaf sibs and their unaffected mother in Family A was apparently a consistent finding. This constriction was considerably longer than the secondary constriction of chromosome No. 9 often noted in some cells of normal persons (Palmer and Funderburk, 1965). Since this variation was not noted in the unaffected sib and in one deaf sib in a family presumably showing a recessive mode of inheritance of deafness, it may be deduced that this variation is unlikely to be associated with the gene responsible for the deafness. A familial occurrence of conspicuously elongated secondary constriction of chromosome No. 9 was described by Moores, Anders, and Emanuel (1966), who regarded it as a marker chromosome.

Endoreduplication of cells was noted in the mother and one deaf sib in Family A. Chaudhuri (1965) described a family in which a healthy mother and her son each showed a cell with endoreduplication. In our study, endoreduplication was noted in $0.4 \%$ of 3402 cells from 129 children. Endoreduplication was found in $0.04 \%$ of 8486 cells from 387 newborns studied by Turner and Wald (1965). Bishun and Morton (1965) recorded endoreduplication in $0.23 \%$ of 3023 cells in cultures prepared according to Moorhead et al. These authors suggest that the actual mode of preparation, whereby the blood is placed on ice immediately after collection, might cause endoreduplication. In our investigations, the blood was left at room temperature after collection for about one hour.

Chromosomal breakage, elongated secondary constriction, and endoreduplication have each been described in association with viral infections, irradiation, drug therapy, or certain congenital syndromes. The occurrence of these three phenomena in one family observed over a two-year period suggests the possibility of a familial susceptibility to chromosomal damage of exogenous or endogenous origin.

This study does not confirm the association of an abnormal chromosome No. 16 with deafness, as suggested by Grimaud et al. (1967). In our series, heterozygosity of chromosome No. 16 was found in only one deaf child, though his deaf brother did not show this abnormality. This variation was described by Court Brown et al. (1966) in their random population study.

One deaf child in our study showed an unusually long $\mathrm{Y}$ chromosome. The length of the human $\mathrm{Y}$ chromosome varies greatly and has been found to be constant for an individual, this constancy of length being inherited (Unnerus, Fellman, and De La Chapelle, 1967). Court Brown et al. (1966) reported that $1.9 \%$ of males had unusually long $\mathrm{Y}$ chromosomes, which he defined as being equal to of exceeding in length an autosome of pairs 19/20.

Regarding anomalous chromosomes as markerso it is presumed that the genes causing deafness in Family A (Fig. 4) and Family B (Fig. 6) were not located on chromosomes 9 and 16, respectively. However, the existence of the gene for deafness and the factor causing secondary constriction on the same chromosome could not be disproved since the segregation of the two traits in the families might be the result of crossing-over between the two. Much more family data are needed to support this speculation.

\section{Summary}

Chromosome analysis from peripheral blood in 129 children with congenital familial deafness did not reveal major chromosome abnormalities. Four children showed a high incidence of chromatid aberrations of unknown causation.

In five members of one family, chromosome 9 showed a conspicuously elongated secondary constriction, and possibly could be regarded as a marker chromosome unassociated with the transmission of deafness.

One deaf child showed heterozygosity of chromosomes 16, and another deaf child showed an unusually long $\mathrm{Y}$ chromosome. 
These results are compared with those recorded in a random population sample, and with those reported in a study of a deaf population sample.

This study was supported by a grant from the H. E. W. Children's Bureau, project CB/Israel 17.

We are indebted to Dr. B. Padeh, Prof. J. Wahrman, Mifaal Hapayis and to the physicians and nurses who helped in this work.

\section{REFERENCES}

Bishun, N. P., and Morton, W. R. M. (1965). Endoreduplicated chromosomes. Lancet, 1, 1169.

Chaudhuri, A. (1965). Chromosome endoreduplication in normal controls. ibid., 1, 1118.

Cohen, M. M., Marinello, M. J., and Back, N. (1967). Chromosomal damage in human leukocytes induced by lysergic acid diethylamide. Science, 155, 1417.

Court Brown, W. M., Buckton, K. E., Jacobs, P. A., Tough, I. M., Kuenssberg, E. V., and Knox, J. D. E. (1966). Chromosome Studies on Adults. Eugenics Laboratory Monograph No. 42, p. 91. Cambridge University Press, London.

$\longrightarrow$, and McLean, A. S. (1965). Quantitative studies of chromosome aberrations in man following acute and chronic exposure to $X$ rays and gamma rays. Lancet, $1,1239$.

Engel, E., and Forbes, A. P. (1965). Cytogenetic and clinical findings in 48 patients with congenitally defective or absent ovaries. Medicine (Baltimore), 44, 135.

Francois, J., Matton-Van Leuven, M. T., and Kluyskens, P. (1967). Cytogenetic study of otosclerosis. Acta Genet. med. (Roma), 16, 124.
Grimaud, R., Gilgenkrantz, S., and Bemol, P. (1967). Anomalies morphologiques des chromosomes de la 16e paire et appareil auditif. Acta oto-laryng. (Stockh.), 63, 144.

Mengel, M. C., Konigsmark, B. W., Berlin, C. I., and McKusick, V. A. (1967). Recessive early-onset neural deafness. ibid., 64, 313.

Moores, E. C., Anders, J. M., and Emanuel, R. (1966). Inheritance of marker chromosomes from a cytogenetic survey of congenital heart disease. Ann. hum. Genet., 30, 77.

Moorhead, P. S., Nowell, P. C., Mellman, W. J., Battips, D. M., and Hungerford, D. A. (1960). Chromosome preparations of leukocytes cultured from human peripheral blood. Exp. Cell Res., 20, 613.

Nichols, W. W. (1966). The role of viruses in the etiology of chromosomal abnormalities. Amer. F. hum. Genet., 18, 81 .

Palmer, C. G., and Funderburk, S. (1965). Secondary constrictions in human chromosomes. Cytogenetics, 4, 261.

Ryan, T. J., Boddington, M. M., and Spriggs, A. I. (1965). Chromosomal abnormalities produced by folic acid antagonists. Brit. f. Derm., 77, 541 .

Sawitsky, A., Bloom, D., and German, J. (1966). Chromosomal breakage and acute leukemia in congenital telangiectatic erythema and stunted growth. Ann. intern. Med., 65, 487.

Swift, M. R., and Hirschhorn, K. (1966). Fanconi's anemia. Inherited susceptibility to chromosome breakage in various tissues. ibid., 65, 496.

Turner, J. H., and Wald, N. (1965). Endoreduplication and disease. Lancet, 1, 915.

Unnerus, V., Fellman, J., and De La Chapelle, A. (1967). The length of the $\mathrm{Y}$ chromosome. Cytogenetics, 6, 213.

Winter, S. T., and Dar, H. (1967). Deafness among children in northern Israel. Incidence and etiology. Israel f. med. Sci., 3, 894. 